\title{
Lex Arbitri, Lex Curia and Lex Contractus in Brazilian Jurisdiction
}

\author{
Renata Thiebaut \\ Shanghai Jiao Tong University, Shanghai, China \\ Email: thiebautrenata@hotmail.com
}

Received 4 March 2016; accepted 5 June 2016; published 8 June 2016

Copyright (C) 2016 by author and Scientific Research Publishing Inc.

This work is licensed under the Creative Commons Attribution International License (CC BY).

http://creativecommons.org/licenses/by/4.0/

(c) (i) Open Access

\begin{abstract}
International arbitration arose as a global phenomenon with the growth of transcontinental trade in a progressive smaller world. As its role and importance have become defined, the use of arbitration as an alternative dispute resolution has increased all around the world accordingly. However, even with unified international documents, such as the 1958 New York Convention ${ }^{1}, 1965$ Washington Convention' ${ }^{2}$, 1985-2006 United Nations Commission on International Trade Law, or UNICITRAL Model Law ${ }^{3}$, arbitration has been approached differently domestically, thus facing conflicts or controversies. This paper has as main objective to explain the key points concerning arbitration within the Brazilian legal system. The evolution of arbitration will be studied since the Iberian Union in the colonial era ${ }^{4}$ in order to bring about the formation of its legal characteristics. Besides, the current Brazilian Arbitration Act, promulgated in 1996, will be analyzed focusing on its provision gaps. The Sulamerica-Enesa arbitral award will be the case study of this paper, which will contribute to a better understanding of the increase in conflicts with the use of this method of dispute resolution. Last, an overview of the Brazilian arbitration legislation as well as its "gaps" will determine that in spite of arbitration being successfully implemented in Brazil, there is still an eminent need to improve legislation, which will be substantial to avoid further conflicts in lex arbitri, lex curia and lex contractus within arbitration itself.
\end{abstract}

\section{Keywords}

\section{Dispute Resolution, Contract Law, Lex Arbitri, Lex Curia}

\footnotetext{
${ }^{1}$ Convention on the Recognition and Enforcement of Foreign Arbitral Awards or the New York Convention of 1958.

${ }^{2}$ The Washington Convention of 1965 governs settlement of international investment disputes.

${ }^{3}$ The UNCITRAL Model Law provides a model for a national law of arbitration and the UNCITRAL Arbitration Rules provides a set of rules for an ad hoc arbitration.

${ }^{4}$ The Iberian union was a political unit that governed all of the Iberian Peninsula from 1580-1640, through a dynastic union between the monarchy of Portugal and the Spanish branch of the Habsburg monarchy after the War of the Portuguese Succession.
} 


\section{Historical Background}

Arbitration in the Brazilian legal system, even though is a relatively recent young practice, goes back to the Portuguese colonization for its first legal documents. Its influence came from the Portuguese legal framework of the Afonsine ${ }^{5}$ (1446 a 1521), Manueline ${ }^{6}$ (1512-13 to 1605) and Filipine Ordenances (1580-1640), thus incorporated into the Brazilian laws.

The Filipine Code of $1603^{7}$ provided the possibility of appellation, even before subjecting the final sentence and penalty (da Costa, 2011) as it stated: "If the parties do not appeal in due time the award rendered by the arbitrators, the judgment will be running by ordinary judges, whether the commitment was put worth it or not, as well as the implementation would be given by ordinary judges”.

For the author Luiz Antonio Ferreira Pacheco da Costa, the Filipine Code assured the arbitral awards and permitted appellation independently from the judicial homologation even before subjecting penalty in case dismissal. The possibility of appellation would not appear in the following legislation.

The 1824 Imperial Constitution, brought in the article 160, in verbis:

“Nas civeis, e nas penæs civilmente intentadas, poderão as Partes nomear Juizes Arbitros. Suas Sentenças serão executadas sem recurso, se assim o convencionarem as mesmas Partes”8.

The articles of the 1824 Constitution were based on the use of arbitration to find solution for civil and criminal disputes. Only in 1850 the Brazilian Commercial Code ${ }^{9}$ incorporated arbitration as an acceptable method for trade disputes. The Regulation 757, enacted in 1850, dealt with arbitration for disputes that arose from commercial rent contracts as well as societal conflicts such as liquidation and distribution. Arbitration was thus mandatory under the 1850 Brazilian Constitution, but voluntary under in the 1850 and 1867 Brazilian Constitutions $^{9}$ (Mardegan, 2012).

The first 1891 Republican Constitution of 1891 ruled out arbitration between two individuals, but allowed arbitration in case of war (Article 43, paragraph 11) (da Costa, 2011). Later, amendments to the 1891 Constitution, made arbitration mandatory in certain circumstances, and thus arbitration gained prominence in the constitutional legislation.

In practice, arbitration was adopted for the first time in Brazil in 1863 with the imprisonment of British Marine officers in Rio de Janeiro, by that time, the capital of Brazil. Later, it was adopted to solve territorial disputes between Brazil and Argentina in 1900 and other territorial disputes between Brazil and British Guiana in 1904 and between Brazil and Bolivia in $1909^{10}$ (de Carvalho Campolina, 2008).

The 1916 Civil Code regulated arbitration proceedings and its civil aspects in details, establishing that an employer could comply with judicial agreement resolution concerning property rights available on the Arbitral Tribunal. On the procedural aspect, arbitration gained spaced only in 1939 through the Civil Procedure Code and later, through the 1973 Procedure Code. But it was in the 1946 Constitution that arbitration was regulated as a judicial right of pledge (da Costa, 2011).

Under constitutional matters, the 1969 Amendment 1 of the 1967 Republican Constitution allowed the use of arbitration for international disputes (Mardegan, 2012).

Under the 1988 Constitution $^{11}$, Article 4, paragraph VII establishes that the Federative Republic of Brazil, in its international relations, is ruled by the principles of peaceful dispute settlements for arbitral matters, however, under the Brazilian legal system, specific legislation has prevailed over general ones. Therefore, there was an Arbitration law in Brazil. But it was only with the enactment of the Arbitration Act in 1996 that arbitration became fully regulated on both procedural and substantive features.

\footnotetext{
${ }^{5}$ During most of Portuguese legal history, Portugal and its colonies had an ancient legal system based on a double foundation of medieval local customary law and Roman law, mostly derived from the Corpus Juris Ccivilisor Code of Justinian. The Afonsine Code was established by the King Afonso Henrique but formalized in1454 by Pedro, the Duke of Coimbra.

${ }^{6}$ The Manueline Code was established by the King Manuel I and modified in 1526, 1533, 1580.

${ }^{7}$ Filipine Ordinance or Filipine Code is a compilation of laws that resulted from legal code reform implemented by Philip II of Spain (Philip I of Portugal), during the Spanish domination. At the end of the Iberian Union (1580-1640), the Filipine Code was still the legal framework in Portugal during D. John IV's rule.

8“'In the civil and criminal the Parties shall be able to nominate arbitration judges. Their sentences will be executed without appealing, if both Parties find convenient”.

${ }^{9}$ Decree number 353 from 1845 consubstantiated the article 160. Art. 245 and 294 from the 1850 Constitution.

${ }^{10}$ The territorial disputes between Brazil and Bolivia resulted in Petropolis Treaty of 1903 and was solved through arbitration. The award stipulated that Brazil could annex the former Bolivian state of Acre to its territory after the payment of monetary compensation.

${ }^{11}$ The current Brazilian Constitution is from 1988, which is also the first post-dictatorship Constitution in the country.
} 


\section{The 1996 Brazilian Arbitration Act}

Since the Filipine Code, arbitration rules were broadly modified. But it was only with the 1996 Arbitration Act that its framework was fully implemented in order to fill in the needs of commercial disputes. Within the Act, arbitration arose as a necessary mechanism in the Brazilian legal system.

Despite being a mechanism regulated by Brazilian legislation since the Iberian Union, arbitration was not often adopted for commercial disputes mainly due to the need of homologation the arbitral awards and its lack of enforcement (da Costa, 2011).

Brazil ratified the New York Convention in $2002^{12}$, the Inter American Convention on International Commercial Arbitration (the Panama Convention) in 1995, being also part of the 1979 Inter-American Convention on Extraterritorial Validity of Foreign Judgments and Arbitral Awards (the Montevideo Convention), the Geneva Protocol of 1923 on arbitration clauses, and the Mercosur Protocol on Jurisdictional Assistance in Civil, Commercial, Labor and Administrative Matters, also termed the 2003 Las Leñas Protocol.

One may notice, that the Brazilian Arbitration Act was promulgated before Brazil became a contracting State of the New York Convention in 2002. According to de Albuquerque Cavalcanti Abbud (2010),

One of the objectives of the 1996 Arbitration Act was precisely to overcome the hurdles in putting the New

York Convention into force. With that in mind, the legislator reproduced in the Act (Art. 37-39) the basic provisions of the Convention regarding the recognition and enforcement of foreign arbitral decisions. Thus, since 1996, domestic rules that are very similar to some of the Convention's main clauses have governed the enforcement of foreign awards in Brazil (da Cruz, 2016).

Even after ratification of international Conventions and Protocols, mainly the New York Convention, the Judiciary, in Brazil, has strongly or solely relied on domestic legislation.

Brazilian Actson arbitration, which are in line with the most relevant international documents on the issues, are traditionally the main tool for legal enforcement, even though hierarchically equal with international documents ${ }^{13}$, following the principles lex posterior derogat priori or lex specialis derogate generali.

The 9307/96 Act has 44 articles within 7 chapters, which bring rules concerning arbitral conventions, their effects, arbitration procedures, arbitral awards and their enforcement (de Menezes Reis \& Hogemann, 1997).

The current Brazilian Arbitration Act complies with international standards as well as with the principles of autonomy of will, good faith between the parties, due process, impartiality of the arbitrator, freedom of persuasion of the arbitrator, motivation of the award, autonomy of law or arbitration clause, and exclusive jurisdiction. These basic principles were and are important to align the domestic legislation with the international ones.

Even though the UNICITRAL, for instance, has strongly inspired the $\mathrm{Act}^{14}$, the lack of provision within domestic legislation remained. The 9307/96 Law has silenced in many points, mainly on:

1) Brazilian law does not provide any specific rule for the establishment of arbitration institutions in Brazil. Nowadays, there are several domestic hybrid arbitration institutes all over the country, such as the Brazil-Canada Chamber of Commerce (CCBC), the Sao Paulo Chamber for Mediation and Arbitration (FIESP/CIESP), Conciliation and Arbitration Chamber of the Fundação Getúlio Vargas (FGV), the Corporate Chamber of Commerce in Brazil (CAMARB), the Arbitration and Mediation Center of the American Chamber of Commerce in São Paulo (AMCHAM), Mediation and Arbitration Center of the Portuguese Chamber of Commerce in Brazil and the Market Arbitration Center instituted by BOVESPA/BMF (Câmara de Arbitragem do Mercado (CAM). Besides, foreign arbitrators such as the International Chamber of Commerce (ICC) operate in the country;

2) The Brazilian Arbitration Act does not provide specific rules regarding the effects of the arbitral agreements before third parties;

3) The Brazilian arbitration law has no specific legal provision about the consolidation of separate arbitral proceedings;

4) Brazilian law does not expressly deal with the confidentiality of arbitral proceedings, but it is a common practice within the arbitral institutions and tribunals not to release further information of cases and awards;

5) There is no specific provision under the Brazilian Arbitration Act regarding consolidation of multiple arbi-

\footnotetext{
${ }^{12}$ Brazil ratified the New York Convention, which was voted and passed by the National Congress through the Legislative Decree no. 52.

${ }^{13}$ In Brazil, there is the constitutionality control of international treaties and other legal documents. After the approval by the National Congress and ratification by the Executive Power, all international treaties enter into force into the Brazilian legal system an ordinary Act, except for international Human Rights treaties.

${ }^{14}$ The Brazilian Arbitration Act was strongly influenced by the UNCITRAL Model Law and the Spanish Arbitration Code from 1988.
} 
tral proceedings, although a few of the existing arbitral institutions in Brazil offer specific rules to this effect;

6) There are no specialized federal or public arbitration Courts in Brazil nor specific provisions on the matter. The Brazil International Tribunal of Arbitration Justice and the Brazilian Arbitral Tribunal are non-profit private arbitral tribunals and were established to fill in the gaps of the Judiciary system;

The Brazilian Arbitration Act rules all arbitration proceedings that take place in Brazil. The Act does not differentiate between domestic and international arbitrations, even if there are foreign parties involved or the governing law is not Brazilian law. The only reference in the Act to foreign issues relates to the enforcement of awards, wherein the Act provides that an arbitral award will be deemed domestic if it is rendered in Brazil and it will be foreign if it is rendered out of Brazil, being thus subject to the 1958 New York Convention on the Recognition and Enforcement of Foreign Arbitral Awards regime.

Despite the restraints of the Arbitration Act regarding the issues mentioned on the previous paragraphs, arbitration has been effective in the country. Currently, the most used platform for arbitration is the arbitral institutions, which gives not only confidence to the enterprises that are not familiar with the arbitration procedures, but also provide standards rules as well as full assistance for the parties involved_(da Cruz, 2016).

The number of arbitral cases in Brazil has increased in the past years for different reasons. After the promulgation of the Arbitration Act, relatively clear guidelines to arbitration processes held in Brazil were implemented; besides its main characteristics such as secrecy, time consumption (6 months instead of at least 3 years in the Judiciary), informality and low level of bureaucracy are the advantages arbitration might have compared to litigation (de Carvalho Campolina, 2008). Besides the Arbitration Act, it is paramount to mention another very important issue that has contributed to the popularity of arbitration: the 2010 "Judiciary crisis"15.

Currently, Brazil has nearly 80 million cases awaiting for a judgement ${ }^{16}$.

The Brazilian Judiciary system is inefficient, bureaucratic and slow to act. Arbitration was not a common practice mostly due to lack of tradition or knowledge on the procedure as a whole, but due to inefficiency of the Brazilian Judiciary system, it has had broad space.

Since arbitration is a relatively new practice in the country it has an immense potential to broaden. Once it gains maturity, controversial cases might become more common and the need to improve existing laws will arise accordingly.

Brazil ranks 4 in the use of arbitration, behind the United States, France and Germany ${ }^{16}$. Most of the arbitral cases are related to franchising licensing, societal divergences, minority shareholders against Assembly or majority shareholders, banking, securities and technology related issues.

Due to the confidential character of arbitration in the country, statistics or detailed information of controversial arbitration cases are not publicized, but one specific case has caught attention and it raised a persistent issue in international arbitration, mainly in lex arbitri.

The case Sulamerica $V$. Enesa, (two Brazilian legal entities), brought about conflicts existing within alternative dispute resolution likewise stressed the vulnerability of arbitration.

Sulamerica Securities and Enesa Engineering ${ }^{17}$ entered into risks insurance contract for the Jirau hydroelectric construction in Brazilian territory ${ }^{18}$.

All the insurers and insured companies involved were Brazilian, the subject matter of the insurance and related events in question occurred in Brazil, and the proper law of the policy was Brazilian law. In addition, the contract contained an exclusive jurisdiction and governing law clause appointing Brazil and the seat of arbitration chosen was London, England. There was an extra clause stating that arbitration shall only be exercised if meditation fails, however, there was no express statement related to the law applicable to the arbitration agreement.

Enesa claimed in the Brazilian Court for physical damage suffered by their construction workers and consequential losses of 4 billion reais (equivalent to 1 billion American dollars) under the contract policies against the Sulamerica Securities. Enesa obtained an injunction preventing the insurers from proceeding against Enesa through arbitration until the Brazilian Courts had decided whether or not Enesa was bound to resolve the disputes through arbitration. Meanwhile, the insurers denied liability and started the dispute resolution process through arbitration in England, seeking, therefore, a declaration of non-liability. Sulamerica Seurities obtained

\footnotetext{
${ }^{15}$ Statistics show that there are only 8 judges for each 100 thousand inhabitants.

${ }^{16}$ Raña, 2011.

${ }^{17}$ Sulamerica CIA Nacional de Seguros SA and others v Enesa Engenharia SA and others [2012] EWCA Civ 638.

${ }^{18}$ The Jirau Hydroelectric Power Plant, located on the Madeira River, is one of the main hydroelectric projects that the Brazilian government has developed in the northern region of Brazil.
} 
an interim anti-suit injunction in an English Court, restraining Enesa to continue with the legal proceedings under Brazilian jurisdiction.

Sulamerica Securities argued that arbitration should be held under English law since the contract provided London, England as the seat of arbitration. Enesa, on the other hand, stated that Brazilian law should govern that arbitration procedure, since it was previously stipulated on the agreement. The right to arbitrate any dispute should be, according to Enesa, subject to Brazilian Courts.

The British Court decided that the arbitration should be governed by English law, despite the parties' express choice of Brazilian law, after analyzing three crucial aspects: the express choice, the implied choice, and the closest and most real connection. The English High Court concluded, therefore, that the parties have previously decided on London as a seat of arbitration, being English law the implied choice.

One major concern was that the agreement to arbitrate would only be enforceable under Enesa's consent according to Brazilian law, which would undermine the agreement; hence Brazilian law should not regulate the award (Greenaway, 2012). The England and Wales Court of Appeal dismissed Enesa's appeal and upheld the anti-suit injunction. The final judgment brought Sulamerica as the winner of that case.

The British judge Cooke J. in charge of that case ruled that the arbitration clause included in the policy enables the validity of both Brazil and English legislations: Brazilian legislation for litigation and England for arbitration. The curial law of the arbitration (or the law of the seat of arbitration) prevailed in the decision (Greenaway, 2012).

The Sulamerica-Enesa case has brought new discussion related to the principle of the party autonomy in lex arbitri. Lex arbitri, in its broad definition, means procedural rules of the Court or arbitral tribunal of the place of the arbitration, which may refer to the arbitration rules and/or conflict-of-laws rules applicable in the place of arbitration as well as the arbitration institution procedural rules; (Agnes Oguntosin) or simply put as "the law of the place where arbitration is to take place" in the conflict of laws. Disputes emanate when parties dispute the proper law governing the arbitration agreement, the arbitration process and the country's courts that have jurisdiction over such disputes.

Enesa seeks the Brazilian Court to claim for physical damage against Sulamerica. According to the current Brazilian Constitution and the Arbitration Act, arbitration can initiate by either Judiciary or extra-judiciary means, without the need of homologation of the arbitral award in any of them. Enesa preferred litigation based on the arbitration clause agreement amongst the parties involved that Brazilian law would be the governing Law.

The outcome of this case in Brazilian jurisdiction could differ and could have brought about considerable discussions. There is, however, not a common understanding or doctrine on the issue.

Enesa's lawyer sought to invalidate the contract and to cancel the final arbitral award given by the British Court by raising two points: that difference on the seat or arbitration and the governing law as well as the non utilization of mediation before arbitration, since the contract has stipulated that that arbitration should only be used after the exhaustion of mediation (Pinheiro \& de Vasconcellos, 2012).

If the lex arbitri is not well defined by the parties on the contract or on the arbitration agreement, it might result in further conflicts or deadlocks, since it is wrongly understood as being the laws of the seat of arbitration. It is important to highlight, therefore, that arbitration clauses are not simply a dispute resolution mechanism, but jurisdictional clauses in their own right. Eminent conflicts within arbitration shall be avoided by the time of drafting the contract or agreement between the parties.

\section{Conclusion}

From the Iberian Union arbitration laws to the current Brazilian Arbitration Code, arbitration has changed substantially in nature. The Filipine and Manueline Codes, for instance, understood arbitration as a matter of war and peace, while the 1850 Commercial Code stated that arbitration was mandatory for commercial disputes.

Brazil has ratified the major Conventions and Protocols concerning arbitration, but it was the Brazilian Arbitration Act from 1996 that implemented strong roots to arbitration as well as clear guidelines to arbitration processes held in Brazil.

Arbitration's main characteristics such as secrecy, low time consumption, informality and low level of bureaucracy became the advantages of arbitration over litigation.

The Brazilian law, however, does not: provide any specific rule to the establishment of arbitration institutions in Brazil, nor specific rules regarding the effects of the arbitral agreement on third parties, or specific legal pro- 
vision about the consolidation of separate arbitral proceedings, specific legal provision about the consolidation of separate arbitral proceedings, or specific provisions over specialized federal or public arbitration Courts in Brazil. It does not differentiate between domestic and international arbitrations; nor expressly deal with the confidentiality of arbitral proceedings specific or provision regarding consolidation of multiple arbitral proceedings.

Within alternative dispute resolutions, many concerns and conflicts may surge due to the increasing complexity of international commercial relations. On the one hand, both international and domestic legislations have to be in line with new developments of arbitration disputes, on the other hand, the pre contractual drafting has to be taken into consideration in order to avoid future issues with the arbitration procedure.

The Sulamerica and Enesa case, is a fine example of a dysfunctional agreement. As the seat of arbitration and governing law mismatched, it was ruled which country's courts have jurisdiction over the dispute.

This case law involving two Brazilian legal entities determines that in spite of arbitration being successfully implemented in Brazil, there is still an eminent need to improve domestic legislation, which will be substantial to avoid further conflicts on lex arbitri, lex curia and lex contractus within arbitration itself.

If the arbitration clause is not well settled by the parties, further conflicts or deadlocks may arise. In the Sulamerica-Enesa case, there was a divergence concerning the governing law (Brazilian law) and the seat of arbitration (London, England). Arbitration clauses are not simply a dispute resolution mechanism, but jurisdictional clauses in their own right. It is for this reasons that, in order to avoid eminent conflicts within arbitration, the contract or agreement between the parties should be carefully drafted.

\section{References}

Pinheiro, A., \& de Vasconcellos, M. (2012). Justiça inglesa anunciará regras da disputa sobre Jirau, Consultor Jurídico. Janeiro. http://www.conjur.com.br/2012-jan-12/justica-inglesa-anuncia-proxima-semana-ringue-batalha-jirau

de Albuquerque Cavalcanti Abbud, A. (2010). Fifty Years in Five? The Brazilian Approach to the New York Convention. http://www.bmalaw.com.br/nova_internet/arquivos/Artigos/AAA.pdf

de Menezes Reis, Í., \& Hogemann, E. R. (1997). Consuêlo de Freitas Machado, Abitragem: Noções essenciais—Entendendo a lei número 9.307/96.

http://www.castelobranco.br/sistema/novoenfoque/files/04/REVISTA_ELETRONICA_DE_DIREITO_DA_UCB-ARBIT RAGEM NOCOES ESSENCIAIS.pdf

de Carvalho Campolina, I. M. (2008). Arbitragem no Direito Empresarial: Perspectivas dos sócios e da sociedade, Nova Lima, Faculdade de Direito Milton Campos.

http://www.mcampos.br/posgraduacao/mestrado/dissertacoes/2011/inesmariacarvalhocampolinaarbitragemdireitoempresar ial.doc.pdf

Greenaway, J. (2012). Sulamerica v Enesa Engenharia: Herbert Smith Comment, Practical Law Company. http://uk.practicallaw.com/5-519-6971

Raña, L. (2011). Soluçao Alternativa: Brasil é o quarto país que mais usa a arbitragem, Consultor Jurídico. http://www.conjur.com.br/2011-nov-28/brasil-quarto-pais-usa-arbitragem-mundo

da Costa, L. A. F. P. (2011). A evolução histórica da arbitragem nas relações trabalhistas no Brasil, Jus Navigandi. http://jus.com.br/revista/texto/19812/a-evolucao-historica-da-arbitragem-nas-relacoestrabalhistas-no-brasil

da Cruz, M. M. C. F. (2016). A Lei de Arbitragem e seus efeitos, Câmara de Mediação e Arbitragem de Joinville. http://www.cmaj.org.br/archives/1368

Mardegan, M. B. E. S. (2012). Arbitragem: Um Meio de Acesso à Ordem Jurídica Justa, Âmbito Jurídico. http://www.ambitojuridico.com.br/site/index.php?n_link=revista_artigos_leitura\&artigo_id=8665 